\title{
UT MUSICA POIESIS: DE LA MELODÍA ESENCIAL A LA CANCIÓN POPULAR EN VALENTE Y GIL DE BIEDMA
}

\author{
UT MUSICA POIESIS: FROM THE \\ ESSENTIAL MELODY TO THE POPULAR \\ SONG IN VALENTE AND GIL DE BIEDMA
}

\author{
Marcela Romano \\ Universidad Nacional de Mar del Plata
}

RESUMEN: Este artículo pone el foco en la fertilidad de un recorrido interesante respecto de la vinculación entre poesía y música en los autores del 50, más precisamente en José ÁngelValente y Jaime Gil de Biedma. Sustrayéndome de un análisis concentrado en la teoría y el lenguaje musicales más refinados, me centraré en el vínculo entre estas artes y los proyectos creadores de uno y otro autor, divergentes entre sí aunque deudores de una nueva modernidad, la cual enlaza a su vez con las demandas del campo artístico e intelectual de pertenencia.

Palabras clave:Valente; Gil de Biedma; poesía española; música.

Aвstract:This article focuses on the fertility of an interesting way regarding the link between poetry and music in the authors of the 1950s, more precisely in José Ángel Valente and Jaime Gil de Biedma. Subtracting myself from a concentrated analysis of the most refined musical theory and language, I will focus on the link between these arts and their creative projects, divergent from each other although both in debt to a new modernity, according with the demands of the artistic and intellectual field to which these authors belonged.

KeY words:Valente; Gil de Biedma; Spanish poetry; music. 
Resulta un lugar común la afirmación de que en la oralidad y el canto reside la mentada "esencia» de la poesía. Los poemas de Homero hasta la llegada del racionalismo filosófico en Grecia, que exigió otras formas de enunciación (la prosa dialogada, por ejemplo), las referencias en la Epistula ad Pisones al canto acompañado por la lira, la práctica de la oralidad cortesana y tradicional en la poesía renacentista y el romancero hispano, dan cuenta de esa «disposición». Más allá de que las definiciones esencialistas sean incompatibles con una mirada histórica, porosa y, por lo mismo, cambiante - esto es, verdadera- de la literatura, es cierto, como asegura Elías Rivers, que la poesía termina imponiéndonos la «materialidad primaria» del verso en la diversidad de sus aspectos fónicos (1988: 17). María José Vega, por su parte, en sus estudios sobre la poética de la lírica culta en el Renacimiento, nos dice que

los poemas pequeños, breves sueltos y varios [...] fueron objeto de lectura y sobre todo la base textual de la poesía en música que se difundió en toda Europa mediante cancioneros, libros de rimas, antologías y misceláneas impresos y manuscritos de música y también mediante la enseñanza directa (2004: 20).

Y concluye:

La historia cultural de la lírica europea habría de dar cuenta de las formas de su consumo, de su inserción en unas redes de prácticas sociales, públicas o privadas de las (digamos) marcas de clase de la poesía en música, cantada o con acompañamiento musical y de su condición de evento más que de texto en medios aristocráticos y cortesanos (2004: 20-21).

Estas conclusiones confirman lo aseverado por Rivers, que extiende la mediación de la oralización y de la música más allá de los circuitos populares a los que pudo acceder, por ejemplo, el romancero anónimo tradicional.

Hasta el Modernismo inclusive, la poesía investiga con obstinación estas cuestiones, que van siendo arrinconadas por el encuentro individual, silencioso y visual con el poema. La hegemonía de esta práctica lectora se encuentra ligada a los procesos de transformación del género (de lo épico a lo lírico, de lo colectivo a lo íntimo) y asimismo de los circuitos de producción, circulación y consumo 
cultural, y se acrecienta, desde fines de siglo XIX y hasta la vanguardia, los experimentos caligramáticos y la poesía concreta, con la ideología moderna de la autonomía estética.

No obstante lo expuesto, la poesía española moderna y contemporánea reconoce en las formas orales, tanto en su actualización performática (hoy mismo tan fundamental, y claramente no solo en España) como en las marcas de la propia escritura, esta virtualidad de la voz, lo que Hans Ulrich Gumbrecht, en un espectro mucho más abarcador de prácticas, ha llamado "producción de presencia» (2005) y Jorge Dubatti «artes liminares» (2016). Fugas de significado casi o nunca aprehensibles, «acontecimiento» $\mathrm{y}$ «experiencia» como territorios gnoseológicos para indagar nuevos y viejos fenómenos de la cultura renuentes a toda inscripción ${ }^{1}$ y ya explorados fecundamente por el magisterio de Walter Ong (1986) y Paul Zumthor (1989 y 2007) en lo concerniente, justamente, a la oralidad y sus dinámicas específicas.

Esa potente dimensión oral incluyó a los del 27, en ejemplos como Alberti y Lorca, y antes, aunque con perspectivas encontradas, a Machado y a Juan Ramón. De manera decisiva, en continuidad con el primero, la oralización de sus textos acompañó a Miguel Hernández en la trinchera de la guerra y, luego de esta, los poetas sociales escribieron / hablando y cantando. En esta "producción de presencia» (Gumbrecht) se instalan resonancias atávicas, originarias e inmemoriales de tradiciones mixturadas, la cotidianidad de lo que pasa en la calle o ese gesto heterónomo, «agonístico» de la epopeya (Ong, 1986: 49-50), en la cual lo "poético» supone un entramado de funciones y articulaciones que exceden, con mucho, el campo artístico, y que ha desembocado en la canción de autor cristalizada como tal por los años sesenta, seguramente el género más evidente de ese maridaje entre música y poesía.

«¿Qué falta aún para llegar a la «inmensa mayoría?», se preguntaba Celaya en 1958, recordando la máxima oteriana. Algo que ya

Estamos hablando del convivio de la puesta en escena (Dubatti, 2016), imposible de ser registrado o registrable en su totalidad. Diferentes son la filmación o la grabación sonora, u, otra vez Dubatti, la «desterritorialización» del tecnovivio (2015), prácticas de fijación semejantes a la escritura, dado que inmovilizan el texto, "permiten el clon, la reproducción infinita, idéntica a sí misma» (Romano, 1994: 66), y donde no pueden pervivir los flujos de experiencia de los diferentes actores de estos «acontecimientos». 
no depende totalmente del poeta: los medios de difusión que el Estado controla; la libertad de expresión [...]; el aparato de la propaganda...».Y cierra con una reflexión a nuestro juicio radical: «La revolución poética y la revolución político-social se [dan] hoy en España como si fueran la misma cosa» (Celaya, 1979: 97). Las extendidas reflexiones celayanas en muchos de sus ensayos sobre este tema toman la batuta en un coro dentro del cual participan también otros poetas. El propio Blas de Otero, en sus Historias fingidas y verdaderas, de 1970, deja escapar estas palabras decisivas estrechamente vinculadas a su ya referido escribo / hablando: «la palabra necesita respiro, y la imprenta se torna de pronto el alguacil que emprisiona las palabras entre rejas de líneas. Porque el poeta es un juglar o no es nada» (1980: 37).

Este magisterio de los primeros sociales halló en los autores del 50 resonancias entramadas con otras bien distintas demandas y expectativas, como veremos más adelante. José Agustín Goytisolo, quizá el más «social» de todos ellos, se embanderó tempranamente a favor de la comunión de música y poesía, él mismo en comandita con Paco Ibáñez. En 1994 nos decía, en una entrevista realizada en Mar del Plata (mi ciudad), que «la poesía no es una escritura que se agota en sí misma, y por lo tanto su finalidad va mucho más allá de lo estético y de su divulgación escrita. [...] El apoyo de la canción es en ese sentido formidable. La gente entiende los textos por el oído, por la música, y a partir de allí se atreve a comprar el libro» (Romano, 1995:324). Huelga mencionar la formidable labor de José Agustín Goytisolo en este sentido, y sumamos a la suya la de José Manuel Caballero Bonald, quien en su variopinta actividad publicó Luces y sombras del flamenco, de 1975, o la recopilación discográfica editada por Ariola-Vergara con el título Archivo del cante flamenco, de 1969. También, como productor discográfico, acompañó a cantantes como Rosa León y las Vainica Doble, figuras relevantes de la canción de autor española. Asimismo, conocemos los artículos críticos sobre música publicados por Ángel González en diversos medios y su amor entrañable por la canción comarcana de su Asturias natal, que él mismo entonaba en reuniones amistosas. Omito aquí detenerme en la musicalización de los textos de muchos de ellos (a cargo de Paco Ibáñez, Joan Manuel Serrat, Miguel Poveda, Pedro Ávila, Pedro Guerra y otros), añadidos a un corpus que definió, en gran medida, la labor de los cantautores en su acercamiento a la poesía, aun cuando sabemos que dicho acercamiento se fundó de 
modo distintivo en la autoconciencia de las posibilidades poéticas de las canciones que ellos mismos escribían, algo de lo que hemos hablado reiteradamente y hace mucho en otros lugares (Romano, 1991, 1994, 2010, por ejemplo).

Aquí quiero indagar, en cambio, en la fertilidad de otro camino a mi juicio interesante respecto de la vinculación entre poesía y música en los autores del 50, más precisamente en José ÁngelValente y Jaime Gil de Biedma. Sustrayéndome de un análisis concentrado en la teoría y el lenguaje musicales más refinados (a los que se han aplicado de manera excelente otros), pondré el foco en el vínculo entre estas artes y los proyectos creadores de uno y otro autor, enlazados con las demandas del campo artístico e intelectual de pertenencia.

En el sesgo de sus versos se advierte, en este sentido, la presencia de unas particularísimas figuras de poeta en común, las del poeta-lector, que se van edificando con pulcritud y persistencia a lo largo de sus obras como un signo distintivo, también, de otros poetas del medio siglo. Ambos comparten gran parte de la modernidad literaria reclamada con avidez al promediar la posguerra: una sed que capitaliza experiencias vitales (por ejemplo, Oxford, al igual que Francisco Brines, y los tres, sabiéndolo o no, en la ruta de Cernuda) y, sobre todo, lecturas europeas en lenguas extranjeras (como la anglosajona y la francesa). Si bien Valente y Gil de Biedma se interesan también por la literatura de la Antigüedad (en Brines es rasgo distintivo) y la Edad Media, con distintos grados y corpus de acercamiento, el primero, progresivamente, va incorporando con fervor y de manera singularísima el apasionante mundo de los autores místicos y religiosos: San Juan de la Cruz, Teresa de Jesús, el heterodoxo Miguel de Molinos, los cabalistas judíos (y, en general, el judaísmo como política y poética del exilio, simbólico e histórico), el sufismo y sus pájaros, el budismo zen, los estoicos, los poetas metafísicos ingleses del siglo XVII (lectura compartida con Gil de Biedma), las enseñanzas de Meister Eckhart y Böhme, a los que suma la modernidad y el pensamiento poéticos insulares del experimentalismo esteticista y las vanguardias (desde Mallarmé a Celan, Bachmann y Jabés, por citar algunos nombres).Valente parece recluirse, a partir de estas lecturas, que dialogan con su poesía y con sus ensayos, en una suerte de ermita contemplativa que lo distrae, solo en apariencia, de los ruidos de la calle y de las demandas de la historia. Jaime Gil, por su parte, se deja seducir por una noche que no es la de Juan de la Cruz, sino la noche deseante de los cuerpos 
(fisicos), la noche urbana y canalla, de sótanos negros y discotecas y calles clandestinas y hoteles de una noche, como recordaba él mismo de Eliot: la bohemia del dandi y la del poeta proletario, en una sola imagen de autor donde comparecen la mala conciencia de clase y la consecuente urgencia de una ética poética y, simultáneamente, con ecos de Manuel Machado, una pose lúdica y hedonista, curiosa y desprejuiciada (miembro, al fin, de la gauche divine), que husmea en las culturas populares de su tiempo para caer seducido, en muchas ocasiones, ante ellas.

Por otra parte, como había hecho ya Cernuda, ambos leen a Eliot, y sobre todo al Eliot tardío de los Cuatro cuartetos y al autor de un ensayo inevitable para pensar la tradición como un diálogo en simultaneidad y libremente escogido, la invención del precursor, la identidad de quien escribe: «Tradición y talento individual», publicado por el angloamericano en 1917, será así el punto neurálgico que permitirá a Valente y a Gil de Biedma la puesta en marcha de una serie de operaciones de lectura y de escritura que entroncan con la literatura meditativa en lengua inglesa, de la cual Cernuda y antes Unamuno fueron devotos admiradores. Sus reflexiones críticas y teóricas parecen fundar para muchos de estos extraterritoriales españoles las claves de la poesía contemporánea por cuanto Eliot, en su revisión de la literatura inglesa del siglo xIX, advierte el desplazamiento de las figuraciones confesionales de la subjetividad proporcionadas por cierto romanticismo hacia otras más distanciadas y objetivas: lo que el propio Eliot denomina «correlato objetivo» $\mathrm{y}$, en especial, el «monólogo dramático», la "segunda voz de la poesía» (Eliot, 1957: 94), cultivado entre otros por los victorianos Tennyson y Browning. Estas estrategias de mediación implican la irrupción de una nueva formación discursiva moderna o contemporánea (distinta y a la vez complementaria de las vanguardias históricas) en la que la reticencia sentimental y la severa contención figurativa se unen a la puesta en escena de un "personaje poético», o de «otro» que interrogará con igual severidad - y también con escepticismo- el relato monolítico de la subjetividad. Por otra parte, se dice que fue el propio Valente, en los cortos años de confluencia grupal, quien le acercó a Gil de Biedma otro ensayo decisivo: La poesía de la experiencia, del profesor norteamericano Robert Langbaum (1957). También leído por Cernuda, como se deja claro en su correspondencia, este ensayo resultó para el barcelonés, especialmente, una clave insoslayable para proyectar su propia poesía, junto con The Poetry of Meditation: 
A Study in English. Religious Literature of the 17th Century, publicado en 1976 por Louis L. Martz, cuyo magisterio es consignado en los Diarios de ambos poetas.

El dictum eliotiano de la impersonalización (o «impersonación», como dirá Gil de Biedma muchas veces, entre otras en una carta dirigida al gallego el 30 de noviembre de $1959^{2}$ ) va prosperando en uno y en otro en conciliación con otras búsquedas más singulares y, en más de un sentido, contrapuestas, que atan esta interpelación a la subjetividad poemática en la médula de estos trayectos con la teoría y práctica de la escritura en su relación con la música.

La crítica ante los lenguajes dados desafió a Valente, como poeta, a buscar el "punto cero» donde la palabra, en su ante-forma, no es propiamente escritura, sino, como aseguraba, un «estado de escritura» que supone la destrucción de cualquier sentido preestablecido y, por ello, convoca todos los sentidos posibles: «Borrarse. / Solo en la ausencia de todo signo / se posa el dios» (Al dios del lugar, 1989, en 1992a: 192)3.

Palabras mínimas para una mínima voz, un sujeto poético que pugna por ausentarse, por desaparecer, porque en esa voz callada resuenan otras voces, otros gestos y otras músicas (mejor, otros "cantos»): el flujo constante y poroso de la tradición (esa inevitable conversación con los muertos elogiada por Quevedo y más tarde, anticipamos, por Eliot); el Espíritu de lo poético primordial y transhistórico al que aludía Borges; «esa aptitud que tiene el Universo Espiritual de verse y desarrollarse a través de lo que fue yo», como

2 Jaime Gil, para entonces, ya está escribiendo Moralidades, titulado provisoriamente por esas fechas Coplas y discursos, y le dice a Valente: «este tipo de poesía requiere la conversión del yo que habla en personaje: lo que en ellos está es Jaime Gil de Biedma impersonating Jaime Gil de Biedma. Bien, mi nueva "impersonación" va a ser la de comentarista o locutor de radio. Aspiro a esa mezcla de impersonalidad, oficiosidad, simpatía, thoughtfulness y ligereza que constituye al buen locutor de radio: una impersonalidad personal» (reproducido en Valladares, 2016: 166). Como consigna Valladares, solo se cuenta con las cartas de Gil de Biedma a Valente (en total seis aquí, y tres en la edición epistolar anterior de Andreu Jaume). Desconocemos si hubo o no respuesta a esta cuestión por parte del gallego, pero, como veremos de inmediato, la cuestión de la «impersonalización» lleva a Valente a soluciones bien distintas de las del barcelonés.

3 Esta cita, como todas las referidas a Material memoria, Tres lecciones de tinieblas, El fulgor y el citado Al dios del lugar, ha sido extraída de la edición parcial de su obra, Material memoria (1979-1989), de 1992, consignada en la Bibliografia. 
refería Mallarmé ${ }^{4}$; el Ursatz o movimiento primario musical teorizado por Schenker y presente en los desarrollos dodecafónicos de sus admirados Schönberg, Webern y Boulez; el timstsum o movimiento de contracción de la divinidad revelado a los saberes judaicos por Isaac de Luria (Safed, Palestina, siglo xvi), según el cual En-Sof, para dar lugar a la Creación, debe exiliarse, replegar su presencia.

$\mathrm{Su}$ «deriva» textual (que incorpora tanto traducciones como versiones propias), la cortedad del decir y las superpuestas y encontradas imágenes de sí anticipan en Valente la anulación progresiva del "yo» hacia una noción diversa de subjetividad, una utopía, en verdad, contra la que conspiró su poderosísima y polémica imagen de escritor dentro del campo artístico. Esa utopía nos la descubría él mismo en uno de sus muchos ensayos, «Las condiciones del pájaro solitario», de La piedra y el centro, de 1982:

En el punto de unificación de la forma, la referencia al hombre o al autor - ¿quién es el autor?- está ya de antemano disuelta. La experiencia personal ingresa en el movimiento natural del universo, en el Ursatz [...] La obra es así anónima, como la poesía está, en verdad, hecha por todos (Valente, 1991: 20$)^{5}$.

Una apuesta por la anonimia y la «colectividad» (mejor, aquí, «comunidad» de voces, como lo piensa Pardo en La intimidad) que poco, a nuestro juicio, tiene que ver con la creencia «cordial» respecto de los usos de lo popular que inaugurara Machado y siguieran algunos poetas de las primera y segunda promociones de posguerra. Valente parece reconstruir en su pensamiento poético las huellas (in)visibles, (in)audibles, de un paradójico «inconocimiento» y, también en esa línea, lee y escucha la poesía tradicional «popular» y oral (el cante jondo y sus ondas melismáticas, las cantigas y el romancero) desde el impulso todavía romántico del «origen», como lo hacía Juan Ramón: una voz inmemorial y ubicua, donde la musicalidad y la reconcentración expresivas funcionan dentro de una suerte de teoría poética «negativa».

4 Así lo deja ver en su «Carta a Cazalis» del 14 de mayo de 1867. Estas referencias aparecen en Kristeva, 1981: 92.

5 La cita referida se encuentra en la edición de dos libros ensayísticos del autor, publicada por Tusquets en 1991, y consignada en la Bibliografia final. 
Esta búsqueda crucial lleva a Valente a dialogar con cartografias procedentes de la música en un sentido más vago o más preciso, o muy preciso, según se vea, como han dejado expuesto desde la musicología estudios inmejorables como los de Francisco Escobar Borrego, Juan José Pastor Comín y, más recientemente, Guillermo Aguirre Martínez, a cuyas lecturas remito ${ }^{6}$.

Es Escobar Borrego (2012) quien destaca en la escritura de nuestro poeta un sustrato musical que, más allá de las alusiones y poemarios concretos referentes a la música, se deja oír fácilmente en la escucha de muchos de sus textos. Así, por ejemplo, al azar leemos un poema de El fulgor, de poderoso erotismo:

Moluscos lentos
sembrada estás de mar, adentro
de ti hay mar, moluscos el beber
en ti el mar
para que nunca en ti
tuvieran fin las aguas
(XII, El fulgor, 1984: 160).

Tras la lectura (oral) de este poema, podemos coincidir con Escobar Borrego en que en Valente «la música constituye uno de los ejes esenciales perceptible en las letras entre sí (eufonía, euritmia, rimas interiores o ecoicas, etc.) que se conciben como bases de emisión fónica o vibraciones con repercusiones en el sentido profundo del texto» (2012: 121). Este repliegue de la escucha, o "punto de escucha intermedia — reconocible por una vibración acusmática o resonancia precisa» (2012: 121) se constituye como la base del proyecto creador valentiano en el idéntico repliegue de la escritura y su condición de «umbral»: lugar del intersticio (la pausa gráfica, blanco y silencio) donde los cabalistas judíos se aproximaban al Nombre.

Junto con esta propuesta medular, a lo largo de la producción valentiana encontramos poemas que aluden explícitamente a formas, designaciones y ecos relacionados con la música.También, tres libros específicos de los cuales dos de ellos incursionan en los ritmos de la lírica cantada de origen popular tradicional (me refiero a Breve

6 Agradezco especialmente a este último autor, a quien conocí en el congreso motivador de este dossier, la amabilidad de acercarme su artículo inédito sobre la relación de Valente con el espectralismo, muy útil y revelador para los ejes aquí trabajados y referido en la Bibliografía. 
son y las Cántigas de alén, estas últimas escritas en gallego, por no hablar de la albada o, mejor, estremecedora elegía de No amanece el cantor), y otro, más hermético, en el que nos detendremos brevemente, relacionado con la práctica ritual judeocristiana del oficio de tinieblas: Tres lecciones de tinieblas, de 1980, cuya nota final nos ofrece ciertos indicadores para su lectura y nos permite ir al meollo del tema que nos ocupa.

Los poemas de las Lecciones pueden leerse dentro del imaginario «material» de Valente "como un poema único: canto de la germinación y del origen o de la vida como inminencia y proximidad» (epílogo a "Tres lecciones de tinieblas: una autolectura», 1980, en 1991: 74). El título del libro, que despliega y recontextualiza algunos significados contenidos en las letras del alfabeto hebreo, remite, como el mismo Valente aclara, al género de canto sacro practicado en la liturgia de la casta sacerdotal judía para intentar decir lo innombrable: el nombre de Dios. Este ritual cantado asimismo encuentra su prolongación dentro del cristianismo en el oficio de las Lamentaciones atribuidas a Jeremías. Anterior al ConcilioVaticano II, era llevado a cabo por la Iglesia Católica los días Miércoles, Jueves y Viernes Santo, al caer la tarde, en la Liturgia de las Horas en memoria de la muerte de Jesucristo, tras lo cual las tinieblas oscurecieron el mundo, precipitado hacia el caos de lo increado. Valente en su Diario nos refiere su asistencia a una puesta de las Lecciones del músico barroco francés Francois Couperin, quien las compuso por encargo para las monjas del convento de Longchamp en 1714 con el objeto de que fueran interpretadas en la liturgia recién aludida: «Enero de 1995. En enero de 1995 interpretaron las Lecciones de Couperin (se apagan 17 cirios) en Versalles» (Valente, 2011:339).

En su autolectura de las Lecciones, Valente - que, a diferencia de Celan, en «Tenebrae», como bien indica Esther Ramón (2014: 34), elige la versión judaica del rito mencionado - invoca la ya referida noción de Ursatz de Schenker (1868-1935), concebida como la estructura musical subyacente en su forma más simple, a partir de la cual se originan las versiones de superficie. Reflexionando sobre la serie abierta por Couperin (al que prosiguen Victoria, Tallis, Charpentier...) acota el gallego que

del lento depósito de esas composiciones fue desprendiéndose o formándose un solo principio iniciador o movimiento primario, ese movimiento que subyace en toda progresión 
armónica y que ha sido llamado justamente Ursatz [...] el Ursatz tiene un potencial expresivo universal y por universal, objetivo. La creación dependería de la medida en que el compositor facilite (por tanteo y por espera) la convergencia de su propia energía con el Ursatz. Lo que en música se llama variación, sería, desde ese punto de vista, un modo de meditación creadora sobre el movimiento primario, sobre la forma universal (1991: 73).

El cruce musical de una línea horizontal (la de la historia, el exilio) y otra vertical (la de las letras) destaca en esta última la potencia del «Aleph» en el sentido borgiano, y de la inminencia e infinitud del decir, que es hálito, respiración, pneuma y también silencio. Por lo mismo, estos conceptos, presentes en los desarrollos del dodecafonismo de Schönberg, en el serialismo de Webern, citado abundamente porValente en su Diario y en el espectralismo francés a partir de los 70 (Murail, Levinas, Grisey), que Aguirre Martínez vincula muy bien con la lírica valentiana (2020), son estratégicos para pensar la operatividad de este campo semántico en su relación con la propia poesía del autor. Lo dice Escobar Borrego al emparentar este ejercicio poético con «el predominio del silencio en el espacio sonoro y visual de la partitura de Webern» (2012: 145), como motor fundamental de significación. No podemos dejar aquí de referir, en relación analógica, un poema valentiano muy ejemplificador respecto de la disposición totalizante de los espacios «blancos», que pueden bien aplicarse a sus propios textos mínimos. En «Cerámica con figuras sobre fondo blanco", de Interior con figuras (1976, en 1980: $408)^{7}$, por ejemplo, la mirada «objetiva» es arrastrada hacia el fondo, y no, como se esperaría en la percepción habitual, hacia el primer plano: "cómo no hallar / alrededor de la figura sola / lo blanco». En la intersección entre lo dicho y lo inefable nos encontramos, dice Aguirre Martínez, con «una estética ajena a toda dualidad —-música y ruido, sonido y silencio, inmanencia y trascendencia-》 sugerida por «una palabra cuyo lugar es liminal y ella misma totalidad aún no desmembrada: palabra [...] primera o antenatal» (2020:15).

«Las polaridades de la repetición y de la variación como fuerzas de reconstrucción» de la escritura, según aclara Pastor Comín retomando aquel principio schenkeriano (2018: 363), alcanzan también al

7 Cito por la edición de Seix-Barral, donde se recoge la poesía entre 1953 y 1979, y que consigno en la Bibliografía. 
pensamiento musical y poético deValente respecto, anticipamos, de las tradiciones orales populares, enhebradas con un fondo común de manifestaciones cultas. «Se escribe desde muy hondos posos, desde muy sumergidos ritmos de la lengua, que se nos imponen o hablan en nosotros» (en Rodríguez Fer, 1996: 16), ha dichoValente de la poesía gallega de sus Cántigas, una «biopoética» signada por la «elocuencia del silencio», en palabras de Rodríguez Fer (1996: 1618): un autor «hablado por esa lengua» y por su cultura de origen y del origen (la lírica medieval y la popular gallega), con remisiones intertextuales a Rosalía de Castro. Del mismo modo, el poemario Breve son (1968) escenifica la sensibilidad del oído valentiano ante el octosílabo y la canción popular, donde se repone, otra vez, a Rosalía, traducida de los Cantares gallegos, y se rinde homenaje - también, en una traducción-versión- a quien más tarde inspirara a su adolescente (y perdido) Agone: Isidore Ducasse, conde de Lautréamont.

El romancero ocupa también la atención del poeta. En la entrada del 29/12/74 de su Diario (2011:163) refiere una versión del conocido romance del Conde Arnaldos. No obstante, llama más la atención el relato contenido en el ensayo "Poesía y exilio", de $L a$ experiencia abisal (2004), en el cualValente alude a esa relación a partir de un ejemplo del movimiento sabbataista de la diáspora sefardí, muy vigoroso a partir de la segunda mitad del siglo XviI. El Mesías Sabbatai Tsevi, nos cuenta Valente, luego de leer la Torá y dirigirse a los creyentes, «cantó en lengua vernácula una vieja canción de amor, el romance de Melisenda o Meliselda [...] muy popular entre los exiliados españoles de Turquía», reinterpretado como la consagración del «matrimonio místico entre el Mesías y la Torá» (2004: 116).Y lo cita en un fragmento del que compartiré yo también unos versos: «Esta noche mis caballeros / durmí con una doncella, / que en los días de mis días / no topí otra como ella» (2004: 116).

«Bella, milagrosa duración, continuidad de la poesía, de la palabra, de la memoria» (2004: 116), comenta allíValente, y de la misma manera reflexionará en muchos de sus escritos, cartas y conferencias sobre el cante jondo y sus melismas, sostenidos por el cuerpo y la voz «hacia lo hondo» del cantor, en un intento de reconstrucción intercultural del género a partir de aquella unidad melódica primordial. En diálogo epistolar con Caballero Bonald, a propósito de su novela Toda la noche oyeron pasar pájaros, de 1981, donde se vierten alusiones a los referidos ensayos del poeta sobre el flamenco,Valente dice: «La otra noche oí toda la noche pasar pájaros. Telefoneé a tu 
casa, pero tú dormías, y no oías nada». La alusión parece una mera coincidencia entre el título de una novela (la de Caballero Bonald) y una experiencia vital, pero va más allá, porque de la metáfora del pájaro (crucial en su poética) pasa el orensano al cante y al canto. Aquí replicaValente su interés ensayístico en el tema, que, en sintonía con sus postulados autorreferenciales, desarrollará en el texto homónimo de La piedra y el centro $(1982)^{8}$, donde reflexiona de este modo:

Queda el sentido. La copla es su sentido: su propia - fulgurante y oscura - aparición es su sentido. Por la copla hacia adentro $[\ldots]$ se va hacia infinitos estratos de sentido. Galerías, sumergidos pasillos, fondos. Porque la copla, hasta llegar a esta voz, ha rodado tiempo y tiempo, al igual que la piedra (1991: 16).

Estos modos de comprender la relación entre música y poesía enfatizan la asunción, dijimos, de una práctica de retracción «negativa» del arte frente a los lenguajes patrimoniales e instrumentalizados. En la huella de las reflexiones adornianas (1980) y a contrapelo de las figuras canonizadas del intelectual "comprometido»,Valente empezó, casi desde el principio, a espigar otras soluciones respecto del interrogante de la representación y de la crítica poéticas: un fino trabajo de destrucción y reconstrucción que las lecturas meramente trascendentalistas en torno a su obra no alcanzaron a advertir, confinándola a un autismo autorreferente y sin vocación histórica. A propósito de esto, el gallego cita en su Diario estas reveladoras palabras recogidas de una entrevista a Max Frisch: «El escritor no se retira a una torre de marfil, sino a una fábrica de dinamita. La impugnación del lenguaje dominante puede hacerse negativamente, por el silencio, o positivamente, imaginando nuevas formas de expresión» (Valente, 2011: 2010; entrada de 3/81). En esa búsqueda utópica arraiga, en definitiva, la caligrafia musical de sus versos.

En el caso de Gil de Biedma, sus lecturas preferenciales - a diferencia de la colección ostentosa de los «novísimos» y la del mismo

La copla disparadora del ensayo, y por la que pregunta a Caballero Bonald, es la siguiente: «Fui la piedra y fui el centro / y me arrojaron al mar / y al cabo de largo tiempo / mi centro vine a encontrar». Con ella encabeza Valente el texto citado. Algunas cartas escritas a Caballero Bonald y su correspondiente estudio pueden verse en Romano, 2008. 
Valente- ponen en escena la construcción de una poética pudorosa que disimula el artificio, la auctoritas, en virtud de una doble oferta: la del «poeta en polainas» con que Wystan Auden vestía al escritor contemporáneo liberado de la toga sacerdotal, y, consecuentemente, la oferta de una poesía construida como una calculada conversación con el lector. Allí están Baudelaire y otros simbolistas franceses «menores» como Corbiére y Laforgue, pero, sobre todo, insistimos, la puerta abierta por el Cernuda tardío, con los nombres de Eliot, Auden, Spender, la poesía victoriana inglesa, los románticos novedosamente revisitados por Langbaum en el libro ya mencionado.

Sumado a ello, en el marco de estas páginas, resulta insoslayable la afinidad del poeta barcelonés con la literatura medieval. En un conocido artículo recopilado por Francisco Rico, «La imitación como mediación o de mi Edad Media», de 1985, Jaime Gil relata sus coincidencias con Gabriel Ferrater, anudadas fundamentalmente en el gusto común por aquella literatura, que ofrecía a ambos autores la imagen espejada de sus propias poéticas, las cuales, en las citadas palabras de Ferrater, habían de «tener el mínimo sentido que se le exige a una carta comercial» (1985: 66). La poesía medieval, en opinión de Gil de Biedma, se afinca en un imaginario que representa sus propias «antítesis programáticas»: «contra la autonomía estética del lenguaje, contra quienes reservan la poesía para sus estupefacciones, contra el exceso de estilo, contra la identidad de fondo y forma, contra la abstracta formalización de la experiencia» (1985: 69). Es esta una mirada particularmente "realista» de la literatura medieval, opuesta a muchas claves del cenáculo estrecho de cierta literatura moderna. Rechaza Jaime Gil de esos imaginarios los desbordes subjetivistas, la exaltación de la autonomía artística y, en concordancia, la críptica búsqueda mallarmeana del Libro.

Esta frecuentación de lecturas está demostrada en el análisis que el autor realiza en el mismo artículo de tres de sus poemas ("Albada», "A una dama joven, separada» y la sextina "Apología y petición»), la apelación "didáctica» a un género «moralizante» en su libro de 1966, Moralidades (donde se incluyen estos tres textos), el abundante uso de versos cortos romanceados y, en general, de formas octosilábicas y de arte menor, la apropiación de citas del repertorio oral, etc. Hay que hacer notar en este sentido que Gil de Biedma encabeza su libro de 1966 con una cita muy reveladora del poeta 
y crítico norteamericano Yvor Winters ${ }^{9}$, a través de la cual, según apunta Jonathan Mayhew, se propone «un modelo racionalista de la creación poética» (Mayhew, 1995: 98), del cual son deudoras las formas métricas fijas o rimadas. Un «hallazgo» (si pensamos en el imperio casi autoritario del versolibrismo en la poesía «moderna») del que luego se harán cargo, con una profusión inusitada, los poetas de los 80. Lo que propone y ejecuta Gil de Biedma es un uso bien diferente de esa tradición sublimada porValente en torno de aquellos orígenes inmemoriales, según señalé líneas arriba. Las formas métricas fijas y la disposición pragmática de la literatura medieval llevan a nuestro autor a conciliar sus búsquedas de «impersonación» y elaborada transparencia comunicativa con una lectura de esa tradición, recortando particularmente su narratividad a partir de un ethos compartido con el lector, en una conversación que atraviesa asimismo los versos sciolti de sus poemas de mayor aliento y ritmo más libre. En esta apuesta coagulan la inmediatez de la "experiencia» (vivencial y también fónica, musical) frente a las «ideas», enlazando aquí con Langbaum y con el «hijo de vecino» inspirado por Auden: una síntesis donde los grandes relatos son reemplazados por un anecdotario de acontecimientos de la Historia y de las historias, el valor de la perspectiva individual y experiencial, contextualmente situadas, por encima de todo idealismo transhistórico, en sintonía con su vocación ética social-realista y sus derivas lúdicas. Formas, tonos, personajes, contextos, motivos, "palabras de familia", en fin, que reponen ese sabor a la vez fresco y sapiencial de la tradición oral, recitada y cantada, algo que se empeña en «oír» y que «oye» muy bien Gil de Biedma, disposición trasladada, como veremos, a la reivindicación de prácticas de la cultura popular posteriores ${ }^{10}$.

9 En sus palabras: «the poet tries to understand his experience in rational terms, to state his understanding, and simultaneously to estate, by means of the feelings which we attach the words, the kind and degree of emotion that should properly be motivated by this understanding» (Gil de Biedma, 1990: 82). Junto con el epígrafe de Winters, aparece un pequeño fragmento de «Le grand testament» (1461) de François Villon: "En l'an trenstiesme de mon age, / que toutes mes hontes j'ay beues...». Este intertexto, además de traer la presencia de un poeta medieval enancado simultáneamente en la alta cultura y los márgenes del burdel y la taberna, en la «boue» a la que acuden prestos Baudelaire y Gil de Biedma, incorpora el motivo de la temporalidad, omnipresente en la poética del catalán.

10 En su Diario de Moralidades, que Gil de Biedma comienza a escribir en 1959, se revelan tempranamente otras diferencias irreconciliables con Valente: el rechazo de la pintura abstracta tras una visita al taller de Tàpies, a la que llama «esa dieta de enfermo» (2015: 358; entrada del 8/9/59), y de Juan Ramón Jiménez, por su 
Deteniéndonos entonces en Moralidades, resulta sintomática, en este sentido, la explicitación genérica cifrada en los títulos de muchos poemas ${ }^{11}$ : «Albada» (93), «Volver» (106), en alusión al tango de Gardel y Le Pera, la versión-traducción de Auden en «romance» (109), la «Novela de un joven pobre» escrita en coplas (110), el romance «A una dama joven, separada», la "Epístola francesa», a la manera de Hugo y Baudelaire (114), «Canción» (116), «Años triunfales» en alusión a la «Marcha triunfal» de Rubén Darío (125) y, cerrando el libro, «El juego de hacer versos» (147), también en octosílabos asonantados. Cabría un análisis minucioso de estos textos, desbrozados algunos en otro lugar (Romano, 2007), pero baste decir que muchos combinan la forma estrófica o el tipo textual tradicional con referentes de la cotidianidad y la vida social contemporáneas, a lo que se suma el afán didáctico y crítico, preanunciado por el título del poemario: la canción de alba, por ejemplo, permite el ingreso en el asunto del amor homosexual, a la par que traslada la escena bucólica con su verosímil idealizante a la ciudad, concretamente a una Barcelona diurna llagada por el tedio y los restos cansinos de «amores de una noche»; por su parte, el romance a la dama separada (dedicado a su amante Bel, trágicamente muerta), cuyo título remeda los textos satírico-burlescos de la tradición áurea, incorpora dos motivos (la liberación sexual de la mujer y la crítica al machismo español) ausentes, por razones históricas y culturales, de aquella tradición.

El tema social está abordado también desde una forma tradicional en «El castillo de Luna» (118), referido a los avatares de la vida de un preso político tras la derrota y ahora liberado al cabo de veinte años en la cárcel. Como asegura Rovira, el asunto político es aquí filtrado por la mirada singular, que transforma la mera información en «el diálogo interior con la imagen obsesiva del condenado» $\mathrm{y}$ «su verdadero tema no es la vida trágica de un preso político, sino la relación que la conciencia del poeta establece con esta tragedia» (1986: 285-286). De este modo, y siguiendo a Langbaum, la «experiencia» se impone una vez más a las «ideas», esta vez en la intención textual de fusionar, nuevamente, lo singular y lo colectivo, lo privado y lo

«increíble descenso - hacia la tontería pura- a partir de Diario de un poeta recién casado; curioso cómo una poesía cuyos principales objetivos son la intensidad y la brevedad se queda en palabrería vana» (2015:362; entrada del 3/10/59).

11 Las referencias a los poemarios, poemas y sus respectivas páginas proceden de la edición de Las personas del verbo incorporada en la Bibliografia. 
público, como caras alternativas y complementarias de una misma noción de identidad. El texto, que lleva por epígrafe un fragmento de un romance del ciclo histórico de Bernardo del Carpio («En el castillo de Luna / tenéis al anciano preso...»), está construido con el modelo rítmico de la octavilla aguda utilizada por Espronceda (primer poeta de la modernidad española, según el propio Jaime Gil), del cual se toman, también, los polisíndeton, las enumeraciones encadenadas y algunos usos calificativos: «Y los años en la cárcel / como un tajo dividiendo / aquellos y estos momentos / de buen sol primaveral, / son un boquete en el alma / que no puedes tapar nunca, / una mina de amargura / y espantosa irrealidad» (119). Los modelos referidos (romance, octavilla aguda), propicios a la representación épica y a la virtual oralización y puesta en música, dan cuenta, desde la perspectiva personal, de un caso modélico, como el de los héroes de las gestas. Lo diferencial respecto de la tradición métrica asumida es que esta es exhibida aquí en su naturaleza artificiosa, y, por lo mismo, en su combinación con la «experiencia» del sujeto singular, el paradigma «heroico» se desmantela, o mejor, se reemplaza por una heroicidad más próxima a la del hombre común, en la que se aloja la crítica a la falta de reconocimiento histórico para con los militantes republicanos: «Serás uno más, perdido / viviendo de algún trabajo / deprimente y mal pagado, / soñando en algo mejor...» $(121)^{12}$.

Esta adopción deliberada de la poética medieval, particularmente en sus formas lírico-narrativas tradicionales, virtualmente oralizables, lleva también a Gil de Biedma a la apropiación de otras poéticas orales más contemporáneas (como el homenaje a la canción francesa en la elegía incluida en el referido Moralidades) y de otras relacionadas con las artes del espectáculo. A lo largo de su obra aparecen alusiones a zarzuelas, canciones francesas, el cine e, inclusive, una versión de la «Nit de Sant Joan» del cantautor catalán Jaume Sisa. En efecto, el poema «Canción de verbena», de Poemas póstumos, constituye una versión libre de la canción escrita por Sisa en catalán, «L'instant precís», e incluida en el álbum Nit de Sant Joan, junto con otras de la comedia musical del mismo nombre, cuyo estreno tuvo lugar en Barcelona el 4 de marzo de 1981, a cargo del

12 Para una mayor profundización remito a Romano (2007), donde se realiza un análisis más pormenorizado de Moralidades, haciendo foco en la célebre sextina "Apología y petición». Del mismo modo, aportes interesantes y más recientes son los de Leuci (2011) y Letamendía (2015), incorporados a la Bibliografía. 
grupo «Dagoll Dagom». El poema biedmiano recrea, con su ritmo ligero, el aire del género: «Es el instante al fin, / y la hora más afín / al dulce hechizo de la música: / el baile empieza ya / y el ritmo ondulará / diciéndonos que todo es siempre así» (176). Lo verdaderamente curioso de esta incorporación es que debajo del título Gil de Biedma reconoce la fuente («por Jaume Sisa», agrega) pero autor y versión son incluidos en un libro firmado por otro. Aquí reconocemos las ideas biedmianas en torno a la traducción como «reescritura» o «versión», al igual que en el propio Valente. Pero, a diferencia de este, sumido en el Espíritu primordial o Ursatz de la creación anónima, la convivencia con estos géneros incorporados a la cultura popular urbana pone de manifiesto una intención lúdica, de juego con diversas herramientas del capital simbólico.Y, como en el caso de González, cierta actitud iconoclasta respecto de los límites y jerarquías genéricos entre literatura y medios, alta cultura y cultura popular, etc. En 2001 decía Sisa al diario El País:

Tuve la oportunidad de conocer personalmente a Jaime Gil de Biedma con motivo de la adaptación que hizo de las canciones de Nit de Sant Joan, espectáculo musical en el que participé junto a «Dagoll Dagom» en 1981. Su amigo Juan Marsé había adaptado las partes habladas de la obra y él fue quien nos recomendó a Jaime. Como autor de las letras me reuní con él en varias ocasiones para comentar los textos y encajarlos adecuadamente en la música. Alguna que otra cena cayó y anduvimos de copas en "Bocaccio» más de una noche. En una de esas me expresó su entusiasmo por el trabajo que estaba realizando y me propuso escribir canciones originales: buscar un tema, él escribiría la letra y yo la música y podría hacer un disco en castellano. En ese momento descarté la idea porque tenía otros proyectos y cuando la consideré, unos años después, ya era tarde y estaba muy enfermo. Siempre me he arrepentido de mi falta de reflejos.

Como consta en diversas fuentes, Jaime Gil fue uno de los habitués más conspicuos del grupo barcelonés denominado la gauche divine, que a fines de los sesenta y principios de los setenta reunía un variopinto elenco de escritores, pintores, arquitectos, cantautores, modelos, fotógrafos, ilustradores, académicos, intersectado con integrantes de la llamada Escuela de Barcelona, en una bohemia exquisita cuyas formas de vida y de hacer arte impugnaban el ya tardofranquismo por una vía bien diversa a la del «compromiso» del 
realismo social. Por esos años, otro frecuentador del grupo como Juan Marsé (quien deja un testimonio irónico de estos encuentros en su relato «Noches de Bocaccio», incorporado a la primera edición de Teniente Bravo, de 1987), escribe junto a Jaime Gil y Jaime Camino el guion de una película dirigida por Camino y que protagonizará el por entonces ya muy popular Joan Manuel Serrat: Mi profesora particular, filmada en 1972 junto con la actriz argentina Analía Gadé (Romano, 2020).Años más tarde, en una entrevista concedida a Alex Susanna, el poeta dice estar escribiendo, también junto con Marsé, una adaptación de la popular opereta La viuda alegre, del músico húngaro Franz Léhar, para la actriz catalana Nuria Espert (Susanna, 1986: 163).

Me interesa, en este sentido, traer aquí el gesto camp de un «poemilla», así llamado por el autor en sus diarios (2015: 460; entrada del 13/9/59), posteriormente musicalizado en 2011 por Alejandro Martínez. «La novela de un joven pobre», tal su título, tiene como protagonista a un personaje que transitó por la vida de Gil de Biedma durante su estancia en Manila en 1956: Pacífico «Pat» Rapaport, «un pampango guapísimo» a quien retrata en «Las islas de Circe», de Retrato del artista en 1956 (2000:81), y que vuelve a su vida — como muchos de sus amantes filipinos- más tardíamente. El título evoca el de la novela romántico-realista de Octave Feuillet, de 1858, no azarosamente llevada al cine, con ese paratexto melodramático, en varias latitudes ${ }^{13}:$ si bien no es un texto adscrito a la entrega folletinesca, acusa filiaciones con este pequeño gran género del siglo XIX

13 Las versiones de la novela fueron tempranas y muy numerosas. En Francia, con idéntico título, Le roman d'un jeune homme pauvre, fueron tres (1913, 1927 y 1936). En Italia contamos también con tres adaptaciones cinematográficas tituladas Romanzo di un giovane povero (1942, 1958 y 1995, esta última de Scola, que solo conserva el título, ya que su argumento difiere sustancialmente del original), a las que se suma una serie televisiva emitida por la RAI entre abril y mayo de 1957. En Argentina también tuvimos nuestras versiones: La novela de un joven pobre (1941), ambientada en el Buenos Aires posterior al período rosista (1829 a 1852), protagonizada por el popular actor y cantante Hugo del Carril; y una segunda, titulada Por un caminito, de 1968, que transcurre en la Patagonia y recoge el argumento de Feuillet y su personaje, a cargo de un cantante por entonces también muy popular de origen provinciano, Leo Dan, acompañada por la canción suya llamada, justamente, «La novela de un joven pobre». Es evidente, en este contexto, que la historia fue más vista que leída. Desconocemos las fuentes de inspiración biedmianas, que tanto pudieron ser el libro original como, mejor, la versión cinematográfica italiana de 1958, dirigida por Marino Girolami y traducida como Estampas de ayer o Historia de un joven pobre. Coproducida por España e Italia, en su guion participó Luis Marquina y, en su elenco, actores 
$\mathrm{y}$ principios del $\mathrm{xx}$, cuyos principios constructivos cristalizaron en formatos diversos y posteriores: la radionovela, la telenovela, series actuales como Gran Hotel de la plataforma Netflix y el bestseller, en todas sus mixturas genéricas y temáticas. Desde ese guiño el autor condiciona nuestra expectativa como lectores: la determinación del género mixto del poema («novela») y su asunto («de un joven pobre»), que inserta el texto en el linaje periférico, «menor», dijimos, del folletín, la canción y el melodrama populares. La "narración» siguiente, como consecuencia, se hará cargo de las reglas de este fenómeno decimonónico en diversos aspectos. El metro predominante elegido para la composición del poema es el verso octosílabo, en cuartetas asonantadas, característico de la poesía tradicional española, que permite, en su doble condición «épica» y «lírica», la natural inserción del dispositivo narrativo y el tono sentimental. Esta «novela» nos acerca una historia dispuesta según la legalidad de aquella familia textual codificada y conservadora; esto es, presentación inicial del personaje por su nombre, apellido y lugar de procedencia, aventuras y desventuras del mismo y un final, transgresor respecto de las reglas del género, «abierto», que introduce la perspectiva del hablante en primera: "Adónde habrás ido a parar, / Pacífico, viejo amigo, / tres años más viejo ya? / Debes tener veinticinco» (111). El tono zumbón, lúdico del texto, es deudor también de un registro, como vemos, coloquial, poblado, además, por pequeñas escenas sentimentaloides afines a la poética del tango, la cual, según Gil de Biedma, «me descubrió una forma posible para lograr en verso español efectos parecidos a los de la balada inglesa» (2015: 344; entrada de 26/4/59). La construcción del personaje - asimilable, con deliberación, a un charnego de Cataluña- se afinca en este des-borde propio de los géneros de masas, es decir, provinciano, pobre, campesino, sensible, apaleado por la vida, pero siempre "guapo", todas ellas circunstancias llevadas a la saturación melodramática con la complicidad del lector: «En esas horas miserables / en que nos hacen compañía / hasta las manchas de nuestro traje / hablábamos de la vida / y el pobre se lamentaba / de lo que hacían con él: / "Me han echado a patadas / de tantos cuartos de hotel..."” (111). No obstante, y a diferencia de la novela de Feuillet (en la que el protagonista es un pobre niño rico) y del folletín clásico, donde algún héroe providencial reivindica identidades, saltos de clase y linajes

españoles. Según se infiere, esta versión fue coetánea a la escritura del poema que estamos analizando. 
ocultos en anagnórisis inverosímiles pero del todo auspiciosas para las víctimas del drama social, nada parece ocurrir en este texto, que oblicuamente, jugando y denunciando, hace foco en las miserias de la desigualdad, junto a la rememoración de su amante filipino y la incertidumbre por su suerte.

En su poesía, y especialmente en el libro referido, fue siempre consciente Gil de Biedma de que un poema debe escribirse como una partitura y leerse escuchándolo:

El poema es un organismo acústico. Hay que leerlo de corrido, no deteniéndose línea por línea.Y, en lo posible, en voz alta. Hasta que se inventó la imprenta, la sensibilidad literaria era auditiva: uno entendía mejor si leía en voz alta que si leía en silencio.Y en poesía sigue siendo así. Cuando lees un poema, lo que importa no es entenderlo; lo que importa es que te guste $(\mathrm{s} / \mathrm{r})$.

No obstante, esa sensibilidad y esa empatía son rigurosa y atentamente construidas. Como en Valente, los diarios dan cuenta de su trabajo obsesivo de taller. Muchas son las entradas que describen una suerte de enfermedad con la hechura de los versos, sus poemas como «monstruos», el terror causado por la lentitud y el desgano ante la creación, la memorización recurrente de las variantes, el uso de un profuso léxico musical (por ejemplo, el concepto de «movimiento») y, especialmente, la convicción del andamiaje musical y oralizable de su poesía.

Por eso, leer a Gil de Biedma es asistir a una puesta de ballet: los buenos bailarines nos deleitan con la naturalidad de sus piruetas, pero solo un iluso podría pensar que una sola de ellas no ha requerido sino meses, años, de esfuerzo, rigor y concentración. El resultado es visible: el trabajoso «artificio» se «naturaliza», como observó con lucidez Luis García Montero a propósito de Garcilaso (2000). ¿Cómo medir entonces el «compromiso» del autor catalán? ¿Cómo calificar su palabra moral, sobre todo en el libro analizado? Lejos de una mímesis reproductiva, o del alegato furibundo que desconoce la singularidad del material artístico, Gil de Biedma ensaya - a mi juicio, con óptimos resultados- una po-ética que conjuga, en un solo gesto, los imperativos de la especificidad estética con el de la función social del arte — seria y lúdicamente- La racionalidad de las formas le permite construir una palabra «entera», entonces, 
abierta por igual a la literatura, al juego y a un contexto histórico que sigue reclamando, con urgencia, el nombre de las cosas.

Para cerrar, diremos que en estas líneas hemos asistido, pese a las diferencias y rispideces verificables entre Valente y Gil de Biedma, que se acentuaron con el correr de los años, a la performance de un afilado dúo amebeo que espiga las relaciones de cada cual con la música ensamblándola con interrogantes medulares en un archivo cultural y literario muchas veces intersectado. Así confluyen Valente y Gil de Biedma en la pregunta y la consecuente puesta en crisis de la identidad poemática, el esmero por superar y reconvertir la(s) lengua(s) poéticas y las tradiciones heredadas en una nueva modernidad que aúne emoción y pensamiento, la obsesión creadora y autorreflexiva, el imperativo ético y un ethos consciente de la fecundidad de sus precursores, quienes los vuelven a ambos lectores en verdad afortunados. En estos cruces de sus respectivos proyectos literarios, la relación entre poesía y música toma caminos, hemos visto, divergentes, pero, en cada caso, de una notable lucidez y originalidad. 


\section{BIBLIOGRAFIA}

Adorno, Theodor (1980). «Discurso sobre lírica y sociedad», en Notas de literatura, Barcelona, Ariel.

Aguirre Martínez, Guillermo (2020). «Relaciones entre la poesía de José Ángel Valente y la música espectral», La Palabra (Universidad Pedagógica y Tecnológica de Colombia), e. p. Celaya, Gabriel (1979). Poesía y verdad (Papeles para un proceso), Barcelona, Planeta.

Dubatti, Jorge (2015). «Convivio y tecnovivio: el teatro entre infancia y babelismo", Revista Colombiana de las Artes Escénicas, 9, pp. 44-54.

— (2016). «Teatro-Matriz y Teatro Liminal: la liminalidad constitutiva del acontecimiento teatral», Cena, 19, s/p.

Eliot, T. S. (1947). «Tradición y talento individual», en Los poetas metafísicos y otros ensayos sobre teatro y religión, Buenos Aires, Emecé, pp. 11-23.

— (1979). «The three voices of poetry», en On poetry and poets, Boston, Faber \& Faber Limited, pp. 89-102.

Escobar Borrego, Francisco Javier (2012). «Tres lecciones de tinieblas, de José Ángel Valente: naturaleza musical, claves de poética e implicaciones simbólicas», Enthymema, 6, pp. 118-191.

García Montero, Luis (2000). «Garcilaso de la Vega, la plenitud, el artificio, la melancolía», en El sexto día. Historia íntima de la poesía española, Madrid, Debate, pp. 81-100.

Gil de Biedma, Jaime (1985). «La imitación como mediación, o de mi Edad Media», en Edad Media y literatura contemporánea, ed. Francisco Rico, Madrid, Trieste, pp. 59-87.

_ (1998). Las personas del verbo, Barcelona, Lumen.

- (2000). Retrato del artista en 1956, Barcelona, Lumen.

- (2010). El argumento de la obra. Correspondencia, ed. Andreu Jaume, Barcelona, Lumen.

— (2015). Diarios (1956-1985), ed. Andreu Jaume, Barcelona, Lumen.

Gumbrecht, Hans Urlich (2005). Producción de presencia. Lo que el significado no puede transmitir, México, Universidad Iberoamericana.

Kristeva, Julia (1981). Semiótica I, Madrid, Fundamentos.

Leuci,Verónica (2011). «Jaime Gil de Biedma y la tradición: reescrituras y relecturas en la poesía del "medio siglo"”, en Actas del IX Congreso Argentino de Hispanistas "El Hispanismo ante el Bicentenario», La Plata, http://ixcah.fahce.unlp.edu.ar. 
Letamendía, Nora (2015). «Jaime Gil de Biedma y la reescritura de la tradición española medieval», en Actas del V Congreso Internacional Celehis de Literatura (Literatura argentina, española y latinoamericana), Mar del Plata, http://humadoc.mdp.edu.ar:8080/handle/123456789/348.

MayHew, Jonathan (1995). «Jaime Gil de Biedma’s Moralidades: Rationalism and poetic forms», en The poetic of self-consciousness. Twentieth century Spanish poetry, London \& Toronto, Associated University Press, pp. 96-105.

Ong, Walter (1986). Oralidad y escritura. Tecnologías de la palabra, México, FCE.

Otero, Blas de (1980). Historias fingidas y verdaderas, Madrid, Alianza Editorial.

Pardo, José Luis (1996). La intimidad,Valencia, Pre-Textos.

Pastor Comín, Juan José (2018). «Estructuras musicales en la obra poética de José ÁngelValente: de Schenker a Guillaume de Machaut», Cuadernos de Investigación Musical, n. ${ }^{\circ}$ Extra 6, pp. 360-372.

RAMÓN, Esther (2004). «Tres lecturas de tinieblas», Cuadernos Hispanoamericanos, 763, pp. 26-39.

Rivers, Elías (1988). «La oralidad y el discurso poético», Edad de Oro,VII, pp. 15-20.

Romano, Marcela (1991). «En torno a una canción

“diversa”", Revista del CELEHIS, 1, pp. 135-144.

_ (1994). «A voz en cuello: la canción de autor en el cruce de escritura y oralidad», en Laura Scarano, Marcela Romano y Marta Ferrari, La voz diseminada. Hacia una teoría del sujeto en la poesía española contemporánea, Buenos Aires, Biblos, pp. 55-68.

— (1995). «Escribir, decir, cantar: una utopía empecinada. Charlando con José Agustín Goytisolo y Paco Ibáñez», Revista del CELEHIS, 4/5, pp. 323-331.

— (2007). «La palabra moral de Jaime Gil de Biedma: una cuestión de formas», La Nueva Literatura Hispánica, 11, pp. 273-290.

— (2009). «Extraterritoriales: unas cartas de José Ángel Valente a José Manuel Caballero Bonald», Campo de Agramante, 12, pp. 9-34.

— (2010). «En canto y alma: poetas y cantautores tras la inmensa mayoría», en Compromisos y palabras bajo el franquismo. Recordando a Blas de Otero (1979-2009), eds. Araceli Iravedra y Leopoldo Sánchez Torre, Sevilla, Renacimiento, pp. 405-427.

— (2020). «El noi y la literatura: sociedades y sociabilidades desde los años barceloneses de la gauche divine», Reseñas/ Celehis, 19, 7, pp. 51-56.

Rovira, Pere (1986). La poesía de Jaime Gil de Biedma, Barcelona, Edicions del Mall. 
SisA, Jaume (2001). «Gil de Biedma en el teatro», El País, 27 de julio, https:// elpais.com/diario/2001/07/28/catalunya/996282466_850215.html.

Susanna, Alex (1986). «Inter pocula (Diálogos informales con Jaime Gil de Biedma)», Litoral [«Jaime Gil de Biedma. El juego de hacer versos»], 163-165, pp. 159-167.

Valente, José Ángel (1980). Punto cero. Poesía 1953-1979, Barcelona, Seix Barral.

- (1991). Variaciones sobre el pájaro y la red precedido

de La piedra y el centro, Barcelona, Tusquets.

_ (1992a). Material memoria (1979-1989), Madrid, Alianza Tres.

_- (1992b). No amanece el cantor, Barcelona, Tusquets.

(1996). Cántigas de alén, ed. bilingüe y prólogo de Claudio

Rodríguez Fer, Santiago de Compostela, Consorcio de Santiago.

- (2000). Fragmentos de un libro futuro, Barcelona,

Galaxia Gutenberg / Círculo de Lectores.

—_ (2011). Diario anónimo, ed. Andrés Sánchez Robayna, Barcelona, Galaxia Gutenberg.

Valladares, Saturnino (2016). Retrato de grupo con figura ausente. Edición

$y$ análisis de la correspondencia entre José Ángel Valente y los poetas españoles

de su edad, Orense, Deputación Provincial de Ourense.

Vega Ramos, María José (2004). «Poética de la lírica en el Renacimiento», en

Idea de la lírica en el Renacimiento: entre Italia y España, eds. Cesc Esteve Mestre

y María José Vega Ramos,Vilagarcía de Arousa, Mirabel, pp. 15-43.

Zumthor, Paul (1989). La letra y la voz. De la literatura medieval, Madrid, Cátedra.

(2007). Performance, recepção, leitura, trad. Jerusa Pires

Ferreira y Suely Fenerich, São Paolo, Cosac Naify. 